\title{
The role of environmental concern in explaining attitude towards second-hand shopping
}

\author{
Barbara Borusiak, Andrzej Szymkowiak, David Bernardo Lopez-Lluch, Paola Sanchez-Bravo
}

\section{A B S T R A C T}

Objective: The objective of the article is to examine the role which environmental concern plays in explaining attitude towards second-hand shopping and the intention to go on a second-hand shop visit.

Research Design \& Methods: The Norm Activation Model, including an additional variable - environmental concern, was used as the main theoretical framework. The research was conducted in Spain and Poland in 2019, with data collected among 403 respondents in Spain and 438 in Poland via the CAWI method, which was further processed using SEM.

Findings: The research allowed to indicate that the influence of environmental concern on attitudes (AT) towards second-hand shopping (SHS) is higher in Spain than in Poland, but the ascription of responsibility for environmental issues has a low level of impact on AT in both countries. The awareness of the consequences has a similar level of influence on AT in both countries and this to a highest degree.

Implications \& Recommendations: Providing products with a second life supports the development of a circular economy, but this requires positive attitudes of individuals, which may be built to the greatest degree by strengthening the ascription of responsibility for the environment.

Contribution \& Value Added: To fill a gap in literature on the subject in the study, it was aimed to develop a model explaining the impact of environmental concern on individuals' attitudes towards second-hand shopping.

Article type: research article

Keywords: $\quad$ environmental concern; second-hand shopping; Norm Activation Model; purchase attitude JEL codes: $\quad$ D12, Q56

Received: 17 July $2020 \quad$ Revised: 2 February $2021 \quad$ Accepted: 3 February 2021

\section{Suggested citation:}

Borusiak, B., Szymkowiak, A., Lopez-Lluch, D.B., \& Sanchez-Bravo, P. (2021). The role of environmental concern in explaining attitude towards second-hand shopping. Entrepreneurial Business and Economics Review, 9(2), 71-83. https://doi.org/10.15678/EBER.2021.090205

\section{INTRODUCTION}

Second-hand shopping (SHS) intensively supports a circular economy, the fast development of which has been observed due to the increasing threat of climate catastrophe. SHS is defined as buying goods which were previously possessed by someone else (Roux \& Guiot, 2008). It is an old phenomenon. For hundreds of years, people have exchanged, sold, bought and used second-hand products, but this did not attract much attention of researchers (Damme \& Vermoesen, 2009). The rising power of production and producers, as well as new products in general were in focus. For years, second-hand products were associated with poverty, people used second-hand products mainly because they could not afford to buy new ones or they experienced a shortage of products, which was characteristic for socialist countries (Rulikova, 2019). However, what we have been observing for about 30 years, is the rapid growth of used product consumption, also in wealthy countries (Guiot \& Roux, 2010). This has also gained a lot of interest of researchers in recent years (Abbes, Hallem, \& Taga, 2020; Fernando, Sivakumaran, \& Suganthi, 2018; Herjanto, Scheller-Sampson, \& Erickson, 2016; Liang \& Xu, 2018; Michno, 2019; Schallehn, Seuring, Strähle, \& Freise, 2019). It is a kind of paradox that people who can afford to buy new items prefer to buy used ones. Why do they do that? The motivation is complex but it includes 
economic factors (on the basis of price orientation, the power of bargaining, as well as critical orientation); ideological motivation - the need to be unique and nostalgia (Padmavathy, Swapana, \& Paul, 2019), as well as hedonic and recreational motives - treasure hunting (Guiot \& Roux, 2010). Ecological reasons for buying second-hand products have also been tested, but the results are not clear. Some results show that purchasing vintage or second-hand clothing is not directly motivated by ecological awareness (Cervellon, Wigley, Carey, \& Harms, 2012). But other research provides evidence that the perceived sustainability of buying second-hand products positively influences the attitude towards buying them (Ek Styvén \& Mariani, 2020). What is also important, there is great diversity of environmental reasons or being willing to act sustainably among consumer groups (Clausen, Blättel-Mink, Erdmann, \& Henseling, 2010). The aim of this article is to examine the role of environmental concern (EC) in explaining second-hand shopping and then the intention to visit a second-hand shop. The Norm Activation Model was used as the main theoretical framework because environmental behaviour is related to people's values (Poortinga, Steg, \& Vlek, 2016; Saleem, Eagle, Yaseen, \& Low, 2018). We took EC into account by including a separate variable used for measuring general attitudes towards environmental issues and by designing two other independent variables derived from NAM: ascription, of responsibility as well as consequence awareness within the context of the environment. To the best of our knowledge, there have been no studies in which a model has been built and tested that would explain the attitude toward second-hand shopping or the intention to make a second-hand shop visit using the above mentioned variables.

Our study was conducted among 842 respondents from two countries, Poland and Spain, which strongly differ in terms of environmental concern; in Poland it is rather low, whereas in Spain it may be considered one of the highest in Europe (Poortinga et al., 2018). Structural equation modelling was implemented to conduct data analysis. The article has the following structure: the concept of environmental concern and its impact on consumer behaviour is first presented; then, second-hand shopping both in Poland and in Spain; and - as the last part of literature review - the hypotheses are developed. Finally, the method of collecting and processing the data is described, the results discussed and the conclusions presented.

\section{LITERATURE REVIEW}

The notion of concern for the environment and its influence on consumer behaviour

Environmental concern may be defined as one's perception and conviction that humans cause danger to the natural environment, and at the same time, are paradoxically, willing to protect it (Fransson \& Gärling, 1999). Researchers apply this term when referring to a myriad environment-related conceptions, emotions and knowledge, as well as attitudes, values or behaviours (Bamberg, 2003). This concept entails, inter alia, three aspects: i) the rational awareness of a problem, ii) emotional affection due to a problem, and iii) willingness to undertake action in solving a given problem (Franzen \& Vogl, 2013).

Environmental concern may be considered as the awareness of consequences when applying the norm activation theory of altruism proposed by Schwartz (1977). Empirical evidence indicates that concern for the environment may have major influence on pro-environmental behaviour. From this perspective, it seems to induce a sense of responsibility towards action, pushing a norm that is personal, or moral obligation towards acting in a certain manner (Kumar, Manrai, \& Manrai, 2017). Proenvironmental norms mirror the degree to which an individual experiences some personal obligation towards contribution to solving an environment-related issue (Stern, 2000).

Attitudes concerning environmental issues are dependent on the relative significance that an individual places on himself, humankind, as well as the planet as a whole (Klöckner, 2013). According to Stern and Dietz (1994), the aforementioned attitudes may be connected to environmental consequences, categorised as egoistic or social-altruistic, and furthermore, biospheric outcomes concerning to three various underlying orientations of values. This value-basis theory could be considered as an extension of the Schwartz (1977) norm-activation model of altruism. It would suggest that environmental issues come forth due to people becoming conscious of the detrimental effects on something valued by them. 
It seems interesting to view not only personal differences, but also those at a national level when considering environmental concerns, which are strongly linked with wealth of the nation. People residing in richer countries demonstrate greater concern for the environment. Individuals' environmental concern is affected by how wealthy a country actually is (Klöckner, 2013).

Nonetheless, differences from country to country are less defined than those found for individuals within a given country. According to Franzen and Vogl (2013), the environmental concern a person experiences is based on socio-demographic factors, i.e. gender, age, annual income and level of education. Furthermore, environmental concern is also linked to general trust towards others, affiliation to a party, as well as post-material values. Females tend to experience more concern than males. This may have its explanation in viewing various social roles. Those younger exhibit higher concern than older individuals, probably for the reason that their upbringing was during times of media attention focused on this issue. Nevertheless, environmental concern first shows an increasing trend to then decrease along with the aging process. Income level is further connected with environmental concern. Along with an increase in income, the higher the level of concern for environmental problems. Two facts allow us to find an explanation for this phenomenon. First of all, the affluent do not consider economic problems to be a concern. Thus, they may move on to other queries. Secondly, those with higher material status, as a rule, are more consumption-oriented, purchasing private goods and having a higher demand for public goods. Their willingness to pay the price for better-quality public goods is higher. Finally, education level is directly linked to environmental concern (Zsóka, Szerényi, Széchy, \& Kocsis, 2013). If one's knowledge regarding environmental problems is higher, their concern for these issues is analogously greater.

Moreover, the orientation of values also regards environmental concerns. This may be explained by viewing the post-materialism hypothesis proposed by Inglehart (Inglehart, 1997). This theory indicates that when faced with changes, a society tends to develop economic-wise, while an economic crisis causes further generations to have higher materialistic values (i.e. economic growth, stability of prices). Generations that grow up in the conditions of economic prosperity demonstrate stronger postmaterial values (freedom as well as self-realisation). Post-material values have a positive connection with concerns for the environment for economic prosperity is not a matter to be solved.

Environmental concern turns into environmental behaviour when people make the decision to act. There are several types of pro-environmental behaviours. Determinants of action and their influence are varied. One group of environment-related behaviours is linked with the concept of frugality (reduction of use, recycling, re-using objects) (Fujii, 2006). In this sense, second-hand buying could be considered as an environmental behaviour related to the concern about the limited availability of natural resources. An attitude that is frugal is connected with cooperative behaviour in dilemmas regarding resources or behaviours concerning their conservation (Wilke, 1991). This requires motivation to save these resources, the concept of "efficiency", as well as strong confidence placed in others. The other side of second-hand buying is linked to the fact that some people that buy and use second-hand products may do so simply because they do not have the money to afford to buy new ones. This could be in connection with the egoistic outcomes pointed to by Stern, Dietz, and Kalof (1993) as frugal behaviour can be explained because of monetary cost savings.

The history of selling used products is quite long. Before the industrial revolution, when the supply of goods was not sufficiently large, all groups of people used to buy second-hand products, including even those affluent. Mass production caused a huge increase in supply, thus access to the offer of new products became much easier. The charity shops organised in Britain were very likely the first outlets oriented towards the sale of used products (Borusiak \& Kucharska, 2019).

\section{Second-hand shopping in Poland}

In Poland people have used second-hand goods for years, but they did not buy them. They were distributed among family members or neighbours. The first shops with second-hand products appeared in Poland in the 60s of the 20th century and they offered products imported from Western Europe. They operated as commission stores, so goods were purchased from individuals who obtained them in the form of private imports. Products sold in those shops were recognised as high-quality, unique, desirable and quite expensive (Berlińska, 2008). But at the beginning of the 1990s, a new type of shop appeared - 
offering used products (mainly clothes) imported on a huge scale from Western Europe. The products were very cheap (they were sold by weight) and very poorly presented. At the same time, Poland started to undergo an economic transformation which, at first, resulted in a high level of unemployment. People shopped at second-hand stores because buying new clothes and other products was not within their economic reach, thus buying used products was associated with economic necessity and low material status. Due to the results of research conducted in Poland in 2019, subjective norms (injunctive) regarding second-hand shopping were negatively related to second-hand product purchase intention. This means that bad associations with SHS still exist and second-hand shopping is not a desired behaviour. But what is also very important, the results of the same study show that personal norms regarding second-hand products are positively related to SHS intentions (Borusiak, Szymkowiak, Horska, Raszka, \& Żelichowska, 2020). It is hard to assess the size of the used products market in general. It consists of two main segments: cars and fashion. Buying used cars in Poland is regarded to be smart shopping (due to the significant price drop of a new car even after short usage), although automobiles are not actually sold in second-hand shops. The number of shops in Poland was estimated at over 30000 entities in 2015 (and still growing), mainly selling clothes. Approximately half of Polish society visits them, mainly for economic reasons and due to economic motivation (Rybowska, 2017).

\section{Second-hand shopping in Spain}

There are not many studies concerning second-hand buying in Spain. Traditionally, Spanish people have bought and used second-hand products for generations. This behaviour was linked to scarcity and poverty. Nowadays, two additional orientations are related to second-hand buying: fashion and sustainability. It can be said that it is more probable that consumers who are materialistic and environmentally-friendly will support the latter than those who are not. According to Mercado Nacional de los Mercados y la Competencia (MNMC) (2019), in 2018, 32\% of second-hand buying was books and music, electronics totalled $14 \%$ (smartphones, ipads, etc.), $13 \%$ clothes and shoes, $11 \%$ was dedicated to furniture. The rest included sports (7\%), cars (6\%) and bicycles (6\%). Furthermore, the value of second-hand buying through e-commerce in Spain grew from almost 20 million Euros in 2014 to almost 36 million Euros in 2017 (MNMC, 2019). This illustrates that it is a growing sector for some types of products, especially those related to an old-fashioned image.

In general, it is not clear how much second-hand buying is due to sustainability concern, to fashion or financial reasons in Spain. However, according to the Second Hand Effect report (2016), $\mathrm{CO}_{2}$ emissions in Spain decreased in 2016 by more than 700000 tons thanks to the used products market development. Among all the categories presented in the report, the so-called "vehicle" sales supported gas emission reduction the most - by 0.6 million tons. This reduction in the emission of carbon is equivalent to eliminating the negative results of all the traffic that a city like Madrid generates in almost three months or the production of almost three million sofas. Regarding savings generated in other categories, 65000 tons stand out in the "home" sector or the 60000 in "electronics". They are followed by such categories as "children and babies" (13 072) and "leisure and sports" (13 702).

\section{Hypotheses development}

As mentioned above, the Norm Activation Model (NAM) was applied as the main theoretical framework. The NAM is widely used for explaining the motives of altruistic, pro-social behaviour which benefits other people (Bamberg, 2012; Saleem et al., 2018; Schwartz, 1977). Pro-environmental behaviour is regarded to be a special case of pro-social behaviour. According to the NAM, a person's pro-social and pro-environmental personal norms, intentions as well as behaviours can be explained by two main variables or constructs: awareness of consequences $(A O C)$ and ascription of responsibility (AOR). Being aware of consequences suggests whether a person is aware of any negative consequences that may be experienced by others or for those things an individual values when not acting in a pro-social manner. Ascribing responsibility is described by feelings of responsibility for negative consequences of not being pro-social. They influence pro-social behaviour with a personal norm as a mediator (De Groot \& Steg, 2009). In the current study, AOC is related to the consequences of second-hand shopping for the 
environment. According to the objective of this study, the awareness of consequences may be considered an important element predicting the attitude towards second-hand shopping (SHS) on the environment, which enables us to formulate the first hypothesis as follows:

H1: Being aware of the consequences $(A O C)$ related to second-hand shopping on the environment has a positive correlation with the attitude towards second-hand shopping (AT) both in Poland ( $\mathrm{H} 1 \mathrm{a}$ ) and in Spain ( $\mathrm{H} 1 \mathrm{~b})$.

The second variable -ascription of responsibility in this study is also related to environmental issues, thus, our second hypothesis was erected as the following:

H2: Ascribing responsibility for environmental concerns (AOR) has a positive correlation with the attitude towards second-hand shopping (AT), both in Poland (H2a) and in Spain (H2b).

As the main focus of this research is connected with environmental concerns, we included that variable into the research model and formulated the following hypothesis:

H3: Environmental concern (EC) is positively related to the attitude towards second-hand shopping (AT), both in Poland (H3a) and in Spain ( $\mathrm{H} 3 \mathrm{~b}$ ).

The final hypothesis is based on the assumption derived from the Theory of Planned Behaviour, stating that individual behaviour can be predicted, inter alia, by a certain attitude towards a given behaviour (Ajzen, 1991). This enables formulation of the hypothesis number four as:

H4: Attitudes towards (AT) thrift shopping have a positive correlation with intention of visiting a second-hand shop (ITV), both in Poland (H4a) and in Spain (H4b).

The proposed research framework is presented in Figure 1.

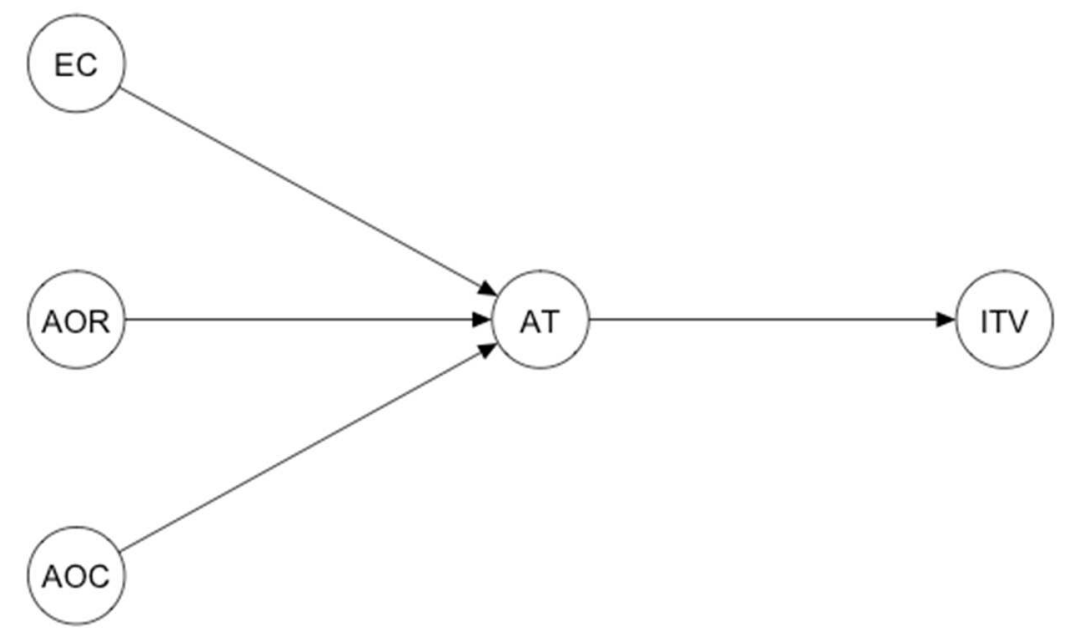

Figure 1. Research framework

Source: own elaboration.

\section{RESEARCH METHODOLOGY}

The study both in Poland and Spain was conducted using a self-administered questionnaire. It contained questions concerning five constructs (variables); attitude towards second-hand shopping (AT), environmental concern (EC), ascription of responsibility for environmental issues (AOR), being aware of the consequences of a SHS for the environment (AOC), intending to make a visit to a second-hand shop (ITV). The respondents provided their comments on the 1-7-point Likert scale 7 (1- meaning "I strongly disagree" to 7 - denoting "I strongly agree"). The list of items used in the questionnaire is presented in Table 1. Participants were recruited from among undergraduate and graduate students of various fields. Participation in the study was voluntary, and participants did not receive any remuneration in Spain (Alicante, Seville, Valencia and Madrid) or in Poland (Poznań, Wrocław, Kraków). Additionally, the authors applied snowball sampling in order to increase the sample size. In total, 841 
fully-completed surveys were collected between January and November 2019, including 438 from Poland and 403 from Spain. The number of participants in both groups is statistically equal to $\mathrm{Chi}^{2}(1)=$ $1.38, p=0.24$. In the case of Polish respondents, the average age was 24.24 ( $S D=6.24$, $\min =17$, $\max$ $=68)$. The study involved 327 women $(75.68 \%)$ and 111 men (25.34\%). The average age in the Spanish group was $22.44(S D=2.56)$ and 329 were women $(81.63 \%)$.

Table 1. Constructs and items applied in the research

\begin{tabular}{|c|c|c|}
\hline Construct & Item & Source \\
\hline \multirow{3}{*}{$\begin{array}{l}\text { Attitude towards sec- } \\
\text { ond-hand shopping } \\
\text { (AT) }\end{array}$} & AT1. I am satisfied when I buy used products. & \multirow{3}{*}{$\begin{array}{l}\text { (Joshi \& Rahman, } \\
\text { 2017; Maichum, Pari- } \\
\text { chatnon, \& Peng, } \\
\text { 2016) }\end{array}$} \\
\hline & AT2. I think buying a used product is beneficial. & \\
\hline & AT3. I think buying a used product is a good idea. & \\
\hline \multirow{3}{*}{$\begin{array}{l}\text { Environmental con- } \\
\text { cern } \\
\text { (EC) }\end{array}$} & $\begin{array}{l}\text { EC1. I have great concern for the state of the environment in } \\
\text { the world. }\end{array}$ & \multirow[t]{3}{*}{ (Maichum et al., 2016) } \\
\hline & $\begin{array}{l}\text { EC2. I feel readiness to reduce my consumption to play my } \\
\text { part in protecting the environment. }\end{array}$ & \\
\hline & $\begin{array}{l}\text { EC3. Major social changes are needed to protect the environ- } \\
\text { ment. }\end{array}$ & \\
\hline \multirow{2}{*}{$\begin{array}{l}\text { Ascription of responsi- } \\
\text { bility for environmen- } \\
\text { tal issues (AOR) }\end{array}$} & $\begin{array}{l}\text { AOR1. All customers need to take on responsibility for envi- } \\
\text { ronmental problems that are caused by industry. }\end{array}$ & \multirow[t]{2}{*}{$\begin{array}{l}\text { (Shin, Im, Jung, \& } \\
\text { Severt, 2018) }\end{array}$} \\
\hline & $\begin{array}{l}\text { AOR2. I think that every customer is partly responsible for } \\
\text { the environmental deteriorations caused by industry. }\end{array}$ & \\
\hline \multirow{3}{*}{$\begin{array}{l}\text { Awareness of conse- } \\
\text { quences of SHS } \\
\text { for the environment } \\
\text { (AOC) }\end{array}$} & $\begin{array}{l}\text { AOC1. In my opinion, second-hand shopping may help de- } \\
\text { crease the pace of exhausting natural resources. }\end{array}$ & \multirow[t]{3}{*}{ (Shin et al., 2018) } \\
\hline & $\begin{array}{l}\text { AOC2. It is plausible that the second-hand may influence the } \\
\text { environment. }\end{array}$ & \\
\hline & $\begin{array}{l}\text { AOC3. The second-hand sector may have effects on climate } \\
\text { changes. }\end{array}$ & \\
\hline $\begin{array}{l}\text { Intention to go to } \\
\text { a second-hand store } \\
\text { (ITV) }\end{array}$ & $\begin{array}{l}\text { ITV1. I am planning to visit a second-hand shop (brick \& mor- } \\
\text { tar or e-commerce). }\end{array}$ & (Shin et al., 2018) \\
\hline
\end{tabular}

Source: own study.

This study was carried out in two stages, as in the proposal by Anderson and Gerbing (1988), indicating to conduct a separate analysis of validity and reliability of the constructs, as well as to test the hypotheses on the basis of the assumed research model applying structural equation modelling. This made it possible to estimate multiple regression equations conceptualised in the model implementing latent variables (Hair, Black, Babin, \& Anderson, 2009). The R programming environment plus Lavaan, Psych and semTools suites were utilised in our analysis.

\section{RESULTS AND DISCUSSION}

Confirmatory analysis was conducted to assess the measurement model reliability and validity (Table 2). CFA results, taking a division into two groups into account, suggest compliance with the values proposed by Hair et al. (2012) $(\chi 2=198.92 ; \mathrm{CFI}=0.98 ; \mathrm{TLI}=0.97 ; \mathrm{GFI}=0.96 ; \mathrm{IFI}=0.98 ; \chi 2 / \mathrm{df}=2.84$; $p<0.00$, as well as RMSEA $=0.06$ ).

All items of factor loading were above the level of 0.71 , exceeding the recommended value of 0.6 (Chin, Gopal, \& Salisbury, 1997). Furthermore, in order to conduct measurements of scale reliability, internal consistency was assessed applying Cronbach's a (Hair et al., 2012; Jarvis et al., 2003). The values obtained for Cronbach's $\alpha$ were within the range of 0.85 to 0.93 in the Polish group, and from 0.71 to 0.87 in the Spanish group, demonstrating good and very good consistency, as suggested in the work by Hair et al. (2012). To measure convergent and discriminant validity, two parameters were applied, that is Composite Reliability (CR) and Average Variance Extracted (AVE) were applied in addition to standardised factor loading. The AVE values came between $0.52-0.82$, giving a total of 0.68 , 
exceeding the acceptable threshold of 0.5 , as proposed by Hair et al. (2009). The CR values also surpassed the acceptable limit equalling 0.6 , the values within the range of 0.77 to 0.94 , totalling 0.96 . The values obtained exceed the recommended values across both sets of data, indicating internal consistency of variables (Bagozzi \& Yi, 1988). The AVE square root was also greater than the correlation between all of the constructs, which further suggests a good level of adequacy (Table 3 ). On the basis of the results presented above, it may be assumed that the presented conceptual model represents good validity, both being convergent and discriminant, as well as reliable.

Table 2. Confirmatory factor analysis

\begin{tabular}{|c|c|c|c|c|c|c|c|}
\hline Country & Construct & Item & Loading & $p$-value & Cronbach's $\alpha$ & CR & AVE \\
\hline \multirow[t]{11}{*}{ Poland } & $A O C$ & AOC1 & 0.903 & $* * *$ & 0.93 & 0.93 & 0.82 \\
\hline & & AOC2 & 0.939 & $* * *$ & & & \\
\hline & & AOC3 & 0.884 & $* * *$ & & & \\
\hline & AOR & AOR2 & 0.917 & $* * *$ & 0.92 & 0.92 & 0.85 \\
\hline & & AOR3 & 0.931 & $* * *$ & & & \\
\hline & AT & AT4 & 0.898 & $* * *$ & 0.93 & 0.88 & 0.77 \\
\hline & & AT5 & 0.856 & $* * *$ & & & \\
\hline & & AT6 & 0.868 & $* * *$ & & & \\
\hline & EC & EC1 & 0.84 & $* * *$ & 0.85 & 0.86 & 0.75 \\
\hline & & EC2 & 0.886 & $* * *$ & & & \\
\hline & ITV & ITV1 & 1 & $* * *$ & & & \\
\hline \multirow[t]{11}{*}{ Spain } & $A O C$ & AOC1 & 0.891 & $* * *$ & 0.77 & 0.76 & 0.52 \\
\hline & & $A O C 2$ & 0.599 & $* * *$ & & & \\
\hline & & AOC3 & 0.714 & $* * *$ & & & \\
\hline & AOR & AOR2 & 0.918 & $* * *$ & 0.87 & 0.88 & 0.78 \\
\hline & & AOR3 & 0.845 & $* * *$ & & & \\
\hline & AT & AT4 & 0.747 & $* * *$ & 0.87 & 0.82 & 0.64 \\
\hline & & AT5 & 0.808 & $* * *$ & & & \\
\hline & & AT6 & 0.858 & $* * *$ & & & \\
\hline & EC & EC1 & 0.765 & $* * *$ & 0.71 & 0.71 & 0.55 \\
\hline & & EC2 & 0.719 & $* * *$ & & & \\
\hline & ITV & ITV1 & 1 & $* * *$ & & & \\
\hline
\end{tabular}

Note: $\alpha$-Cronbach's $\alpha$, CR - Composite Reliability, AVE - Average Variance Extracted, $* * * \leq 0.001$

Source: own calculations.

Table 3. Correlations between constructs

\begin{tabular}{|l|l|l|l|l|l|}
\hline Group & AOC & AOR & AT & EC & ITV \\
\hline PL & $\mathbf{0 . 9 1}$ & & & & \\
\hline & 0.63 & $\mathbf{0 . 9 2}$ & & & \\
\hline & 0.60 & 0.50 & $\mathbf{0 . 8 8}$ & & \\
\hline & 0.51 & 0.53 & 0.46 & $\mathbf{0 . 8 7}$ & \\
\hline ES & 0.49 & 0.46 & 0.64 & 0.42 & $\mathrm{NA}^{\mathrm{x}}$ \\
\hline & $\mathbf{0 . 7 2}$ & & & & \\
\hline & 0.39 & $\mathbf{0 . 8 8}$ & & & \\
\hline & 0.64 & 0.41 & $\mathbf{0 . 8 0}$ & & \\
\hline & 0.43 & 0.38 & 0.53 & $\mathbf{0 . 7 4}$ & \\
\hline & 0.30 & 0.12 & 0.38 & 0.36 & $\mathrm{NA}^{\mathrm{x}}$ \\
\hline
\end{tabular}

Note: values distinguished in bold represent the AVEsquare root $x=$ Construct was measured using one item Source: own calculations.

Empirical analysis applying the assumed theoretical model allowed to reveal a good fit $(\chi 2=182.92$; $\mathrm{CFI}=0.98 ; \mathrm{TLI}=0.97 ; \mathrm{GFI}=0.96 ; \mathrm{IFI}=0.98 ; \chi 2 / \mathrm{df}=2.47 ; \mathrm{RMSEA}=0.06$ ), which may also be implemented in the assessment of influence on attitudes towards second-hand shopping and the intention to go to a second-hand shop via evaluation of the structural model with regard to size and significance 
of path coefficients as well as $R^{2}$. All analysed path-coefficients in both groups were statistically significant and exceeded the 0.10 benchmark (Hair et al., 2012) - see Table 4 . The results allow to suggest that AT formation via the following three components: AOC, AOR and EC, has positive and direct influence on ITV both in Poland and in Spain. Consequently, the results support all the hypotheses formulated in this study. This variance, which is explained via the model in the Polish group, was $48 \%$ for ITV and $49 \%$ for $A T$, while in the case of the Spanish data, $R^{2}$ was $17 \%$ and $58 \%$, respectively.

Table 4. Effects between factors

\begin{tabular}{|l|l|l|l|l|l|l|l|}
\hline \multicolumn{1}{|c|}{ Group } & \multicolumn{1}{|c|}{$\begin{array}{c}\text { Endogenous } \\
\text { variable }\end{array}$} & \multicolumn{1}{|c|}{$\begin{array}{c}\text { Exogenous } \\
\text { variable }\end{array}$} & Beta & B & SE & p-value & Hypothesis \\
\hline PL & AT & AOC & 0.43 & 0.60 & 0.08 & $* * *$ & H1a: supported \\
\hline ES & AT & AOC & 0.49 & 0.75 & 0.11 & $* * *$ & H1b: supported \\
\hline PL & AT & AOR & 0.16 & 0.22 & 0.08 & $* *$ & H2a: supported \\
\hline ES & AT & AOR & 0.10 & 0.16 & 0.08 & $*$ & H2b: supported \\
\hline PL & AT & EC & 0.22 & 0.31 & 0.08 & $* * *$ & H3a: supported \\
\hline ES & AT & EC & 0.35 & 0.54 & 0.11 & $* * *$ & H3b: supported \\
\hline PL & ITV & AT & 0.69 & 0.68 & 0.05 & $* * *$ & H4a: supported \\
\hline ES & ITV & AT & 0.41 & 0.29 & 0.04 & $* * *$ & H4b: supported \\
\hline
\end{tabular}

Note: ${ }^{*}=<.05, * *=<.01, * * *=<.001$

Source: own calculations.

The differences are evident: in Spain, the influence of environmental concerns on the attitude towards second-hand shopping is much higher than in Poland. The influence of the other two variables on the attitude is similar in Spain and in Poland. But what is also interesting, the influence of attitudes towards second-hand shopping on individuals' intentions to go to a second-hand store is higher in Poland than in Spain.

The objective of the study was to analyse the role played by environmental concern in explaining the attitude towards second-hand shopping and the intention to go to a thrift shop. The Norm Activation Model, including an additional variable - environmental concern - is used as a theoretical framework. This model explains motivation for altruistic behaviour which benefits other people. The research was conducted in Poland and Spain. These two countries demonstrate vast differences regarding environmental concern. Spain shows one of the greatest environmental concern levels, but Poland is rated with its low level (Poortinga et al., 2018).

The study was based on four hypotheses. The first three hypotheses look at factors that create people's attitudes. These are the awareness of the consequences of second-hand shopping for the environment (AOC), ascription of being responsible for environmental issues (AOR), and concern for it (EC); which have a positive correlation with the attitude towards shopping at second-hand stores (AT). The last hypothesis relates to how attitude becomes behaviour (Theory of Planned Behaviour); the attitude towards second-hand shopping (AT) has a positive connection with the intention to go to a second-hand shop (ITV). The results confirmed all the hypotheses formulated in the current study. Therefore, it can be said that awareness can create attitude, and attitude can lead to action. However, the reasons for this action can be different. That is to say, people can be aware that their actions have an effect but the reasons for their actions may not necessarily be related to this awareness. In such a sense, there are differences between Spanish and Polish attitudes and behaviours. These results reveal two facts:

- the effects of environmental concern on attitudes towards second-hand shopping are greater in Spain, - the influence of the attitude towards second-hand shopping is higher in Poland.

The variance that can explained by this model in the Polish group was $48 \%$ for ITV and $49 \%$ for AT, in the case of the Spanish dataset, $\mathrm{R}^{2}$ was $17 \%$ and $58 \%$, respectively. This result is in coherence with the findings obtained by Poortinga et al. (2018): $95.7 \%$ of Spanish people agree with the sentence that climate change is at least in part due to the activities undertaken by humans ( $89 \%$ in Poland). These differences may be explained by the socio-economic differences between these two countries. Engagement in climate change seems to be weaker (with exceptions) in Central and Eastern Europe. This 
could be seen as a lasting confidence in the generation of fossil-based electricity, however, it is also the economic state and the pace of transformation among society that is experienced in this field (Balžekiene \& Telešiene, 2017). People living in wealthier countries tend to show higher environmental concern (Klöckner, 2013), but this environmental concern does not necessarily imply that people take all actions positively influencing the environment. In fact, differences that are individual within a country seem to be more strongly defined than those found among various countries (Franzen \& Vogl, 2013). In this sense, according to Poortinga et al. (2018), the opinion that the impact of climate change will be bad (that could be understood as an environmental concern) is supported by $87.9 \%$ in Spain (which is the highest number among all countries), but only by $66.3 \%$ in Belgium, $67.2 \%$ in Finland, $71.0 \%$ in Norway and $77.4 \%$ in Germany. All these countries are wealthier than Spain. This opinion is shared by $70.4 \%$ of Polish people. Furthermore, there may be a link with location, the more to the south of Europe, the higher the environmental concern as these areas may be more exposed to climate change effects. However, this idea is in contradiction to the fact that fossil fuel taxes appear to have more popularity in given Western European countries (Nordic), with a majority only in Sweden and Finland. The tax has the least popularity in Poland and Russia, while being relatively unpopular in the remaining East European and some South European countries, i.e. Spain and Portugal (Poortinga et al., 2018). It may be stated that Spanish people are aware of climate change effects but are not willing to pay for avoiding them. This could also explain second-hand buying in Spain.

The complexity of the reasons for second-hand buying is also demonstrated by the fact that the awareness of the consequence of second-hand shopping for the environment (AOC) and ascription of responsibility towards environmental issues (AOR) have similar influence in both countries.

\section{CONCLUSIONS}

In order to understand second-hand buying habits, it must be taken into account that second-hand product purchase is a clear, sustainable behaviour, but can also be related to fashion-oriented actions or nostalgia (Padmavathy, Swapana, \& Paul, 2019). In many countries (also in Poland and Spain), SHS is also reinforced by the growth of on-line second-hand shopping (MNMC, 2019). Furthermore, another motivation for buying second-hand goods can be poor personal financial situation (Rulikova, 2019) and/or frugality, or the opportunity to buy a product of fairly good quality for a low price (Raszka \& Borusiak, 2020). It seems clear that there is no easy explanation. As pointed out by Poortinga et al., (2018), Europeans, on average, seem to express more concern about energy costs than about climate change; one of the most greatly effective policies being reduction of carbon emission, increasing taxes on fossil fuels, which are considered far less favourable than other policies presented in the study. So, it could be said that people in both countries know the importance of their actions for the environment and that they are aware that second-hand shopping has a positive effect on the environment, but the main reasons for purchasing second-hand items are different in each country. This is also reinforced by differences in explained variances. Furthermore, some of the reasons for second-hand buying are not necessarily linked to environmental concern.

The current research could enable politicians and managers to be aware of how people understand environmental concern and link this concept to their own consumption behaviours, i.e. the attitude towards second-hand shopping. Effective communication campaigns promoting used-product purchases should implement environmental concern as an argument encouraging people to embrace second-hand shopping. These campaigns could contain presentations of the consequences of business models like fast fashion and build consumer responsibility towards the environment.

There are several limitations of the current study. The first is connected with the size and structure of the sample. The sample is not representative as respondents were mainly young; the average age among Polish respondents was $24.24(\mathrm{SD}=6.24)$ and among those Spanish, $22.44(\mathrm{SD}=2.56)$; while women made up the majority of the sample. This could bias the results, as it is known that young people and women are more environmentally concerned. Another limitation is the method of data collection: the applied technique of self-reporting may cause the results to be biased because of the effects of social desirability. Also important seems the fact that no specific products were considered 
in the current research trial, and it is possible that the meaning of environmental concern on attitudes towards second-hand purchases depends on the type of product or even the retail format where it is sold (for example, it may be more favourable on second-hand online platforms).

In future research, it would be interesting to find out the determinants of attitudes towards second-hand purchases other than environmental concern, both in Poland and Spain, and to examine the strength of their impact on these attitudes. In further studies, the influence of environmental concern, responsibility ascription as well as consciousness of outcomes on attitudes towards second-hand purchase in other countries could also be considered in order to verify Inglehart's post-materialism hypothesis. Future research could be devoted to the influence of concern for the environment on intention to behave in an eco-friendly fashion, especially those which are connected with a willingness to accept making economic sacrifices in order to ensure proper protection of the environment.

\section{REFERENCES}

Abbes, I., Hallem, Y., \& Taga, N. (2020). Second-hand shopping and brand loyalty: The role of online collaborative redistribution platforms. Journal of Retailing and Consumer Services, 52. https://doi.org/10.1016/j.jretconser.2019.101885

Ajzen, I. (1991). The Theory of Planned Behavior. Organizational Behavior and Human Decision Processes, 50(2), 179-211. https://doi.org/10.1016/0749-5978(91)90020-T

Anderson, J., \& Gerbing, D. (1988). Structural Equation Modeling in Practice: A Review and Recommended TwoStep Approach. Psychological Bulletin, 103, 411-423. https://doi.org/10.1037/0033-2909.103.3.411

Bagozzi, R., \& Yi, Y. (1988). On the evaluation of structural equation models. Journal of the Academy of Marketing Science, 16(1), 74-94. https://doi.org/10.1007/BF02723327

Balžekiene, A., \& Telešiene, A. (2017). Vulnerable and insecure? Environmental and technological risk perception in Europe. Green European. Environmental Behaviour and Attitudes in Europe in a Historical and CrossCultural Comparative Perspective, 31-55.

Bamberg, S. (2003). How does environmental concern influence specific environmentally related behaviors? A new answer to an old question. Journal of Environmental Psychology, 23(1), 21-32. https://doi.org/10.1016/S0272-4944(02)00078-6

Bamberg, S. (2012). Chapter 9. Understanding and Promoting Bicycle Use - Insights from Psychological Research. In J. Parkin (Ed.) Cycling and Sustainability (pp. 219-246). Bingley: Emerald Group Publishing Limited. https://doi.org/10.1108/S2044-9941(2012)0000001011

Borusiak, B., \& Kucharska, B. (2019). Sustainability in Retailing: A Study of Consumer Intentions Regarding Involvement in Charity Shop Activities. Studia Periegetica, 1(25), 65-85. https://doi.org/10.26349/st.per.0025.05

Borusiak, B., Szymkowiak, A., Horska, E., Raszka, N., \& Żelichowska, E. (2020). Towards Building Sustainable Consumption: A Study of Second-Hand Buying Intentions. Sustainability, 12(3). https://doi.org/10.3390/su12030875

Cervellon, M.C., Wigley, S.M., Carey, L., \& Harms, T. (2012). Something old, something used. International Journal of Retail \& Distribution Management, 40(12), 956-974. https://doi.org/10.1108/09590551211274946

Chin, W.W., Gopal, A., \& Salisbury, W.D. (1997). Advancing the Theory of Adaptive Structuration: The Development of a Scale to Measure Faithfulness of Appropriation. Information Systems Research, 8(4), 342367. https://doi.org/10.1287/isre.8.4.342

Clausen, J., Blättel-Mink, B., Erdmann, L., \& Henseling, C. (2010). Contribution of Online Trading of Used Goods to Resource Efficiency: An Empirical Study of eBay Users. Sustainability, 2(6), 1810-1830. https://doi.org/10.3390/su2061810

Damme, I.V., \& Vermoesen, R. (2009). Second-hand consumption as a way of life: public auctions in the surroundings of Alost in the late eighteenth century. Continuity and Change, 24(2), 275-305. https://doi.org/10.1017/s0268416009007188

De Groot, J.I., \& Steg, L. (2009). Morality and prosocial behavior: the role of awareness, responsibility, and norms in the norm activation model. Journal of Social Psychology, 149(4), 425-449. https://doi.org/10.3200/SOCP.149.4.425-449 
Ek Styvén, M., \& Mariani, M.M. (2020). Understanding the intention to buy secondhand clothing on sharing economy platforms: The influence of sustainability, distance from the consumption system, and economic motivations. Psychology \& Marketing, 37(5), 724-739. https://doi.org/10.1002/mar.21334

Fernando, A.G., Sivakumaran, B., \& Suganthi, L. (2018). Comparison of perceived acquisition value sought by online second-hand and new goods shoppers. European Journal of Marketing, 52(7/8), 1412-1438. https://doi.org/10.1108/ejm-01-2017-0048

Fransson, N., \& Gärling, T. (1999). Environmental Concern: Conceptual Definitions, Measurement Methods, and Research Findings. Journal of Environmental Psychology, 19(4), 369-382. https://doi.org/10.1006/jevp.1999.0141

Franzen, A., \& Vogl, D. (2013). Two decades of measuring environmental attitudes: A comparative analysis of 33 countries. Global Environmental Change, 23(5), 1001-1008.

Fujii, S. (2006). Environmental concern, attitude toward frugality, and ease of behavior as determinants of proenvironmental behavior intentions. Journal of Environmental Psychology, 26(4), 262-268. https://doi.org/10.1016/j.jenvp.2006.09.003

Guiot, D., \& Roux, D. (2010). A Second-hand Shoppers' Motivation Scale: Antecedents, Consequences, and Implications for Retailers. Journal of Retailing, 86(4), 355-371. https://doi.org/10.1016/j.jretai.2010.08.002

Hair, J., Black, W., Babin, B., \& Anderson, R. (2009). Multivariate Data Analysis (7th Edition). Prentice Hall.

Herjanto, H., Scheller-Sampson, J., \& Erickson, E. (2016). The increasing phenomenon of second-hand clothes purchase: Insights from the literature. Jurnal Manajemen Dan Kewirausahaan, 18(1), 1-15. https://doi.org/10.9744/jmk.18.1.1-15

Inglehart, R. (1997). Modernization and postmodernization: Cultural, economic, and political change in 43 societies. Princeton University Press.

Joshi, Y., \& Rahman, Z. (2017). Investigating the determinants of consumers' sustainable purchase behaviour. Sustainable Production and Consumption, 10, 110-120. https://doi.org/10.1016/j.spc.2017.02.002

Klöckner, C.A. (2013). A comprehensive model of the psychology of environmental behaviour - A meta-analysis. Global Environmental Change, 23(5), 1028-1038.

Kumar, B., Manrai, A.K., \& Manrai, L.A. (2017). Purchasing behaviour for environmentally sustainable products: A conceptual framework and empirical study. Journal of Retailing and Consumer Services, 34, 1-9.

Liang, J., \& Xu, Y. (2018). Second-hand clothing consumption: A generational cohort analysis of the Chinese market. International Journal of Consumer Studies, 42(1), 120-130. https://doi.org/10.1111/ijcs.12393

Maichum, K., Parichatnon, S., \& Peng, K.-C. (2016). Application of the Extended Theory of Planned Behavior Model to Investigate Purchase Intention of Green Products among Thai Consumers. Sustainability, 8(10). https://doi.org/10.3390/su8101077

Michno, A. (2019). Second hand - rzecz między starym a nowym życiem. Prace Kulturoznawcze, 22(4), 69-82. https://doi.org/10.19195/0860-6668.22.4.6

Padmavathy, C., Swapana, M., \& Paul, J. (2019). Online second-hand shopping motivation - Conceptualization, scale development, and validation. Journal of Retailing and Consumer Services, 51, 19-32. https://doi.org/10.1016/j.jretconser.2019.05.014

Poortinga, W., Fisher, S., Bohm, G., Steg, L., Whitmarsh, L., \& Ogunbode, C. (2018). European attitudes to climate change and energy. Topline results from Round 8 of the European Social Survey. Retrieved from https://www.europeansocialsurvey.org/docs/findings/ESS8_toplines_issue_9_climatechange.pdf on January 15, 2020.

Poortinga, W., Steg, L., \& Vlek, C. (2016). Values, Environmental Concern, and Environmental Behavior. Environment and Behavior, 36(1), 70-93. https://doi.org10.1177/0013916503251466

Raszka, N., \& Borusiak, B. (2020). Motives of second-hand products purchase - the qualitative study results. Marketing i Rynek, 2020(1), 23-31. https://doi.org/10.33226/1231-7853.2020.1.3

Roux, D., \& Guiot, D. (2008). Measuring second-hand shopping motives, antecedents and consequences. Recherche et Applications en Marketing, 23(4), 63-94. https://doi.org/10.1177/205157070802300404

Rulikova, M. (2019). "I would never wear those old clodhoppers!": Age differences and used clothing consumption in the Czech Republic. Journal of Consumer Culture, 20(2), 175-193. https://doi.org/10.1177/1469540519891274 
Rybowska, A. (2017). Consumers Behavior in the Second Hand Market. Marketing i Zarzqdzanie, 48, 95-104. https://doi.org/10.18276/miz.2017.48-09

Saleem, M.A., Eagle, L., Yaseen, A., \& Low, D. (2018). The power of spirituality. Asia Pacific Journal of Marketing and Logistics, 30(4), 867-888. https://doi.org/10.1108/apjml-10-2017-0259

Schallehn, H., Seuring, S., Strähle, J., \& Freise, M. (2019). Customer experience creation for after-use products: A product-service systems-based review. Journal of Cleaner Production, 210, 929-944. https://doi.org/10.1016/j.jclepro.2018.10.292

Schwartz, S.H. (1977). Normative Influences on Altruism. Advances in Experimental Social Psychology, 10(1), 221279. https://doi.org/10.1016/S0065-2601(08)60358-5

Shin, Y.H., Im, J., Jung, S.E., \& Severt, K. (2018). The theory of planned behavior and the norm activation model approach to consumer behavior regarding organic menus. International Journal of Hospitality Management, 69, 21-29. https://doi.org/10.1016/j.ijhm.2017.10.011

Stern, P.C. (2000). New environmental theories: toward a coherent theory of environmentally significant behavior. Journal of Social Issues, 56(3), 407-424. https://doi.org/10.1111/0022-4537.00175

Stern, P.C., \& Dietz, T. (1994). The value basis of environmental concern. Journal of Social Issues, 50(3), 65-84. https://doi.org/10.1111/j.1540-4560.1994.tb02420.x

Stern, P.C., Dietz, T., \& Kalof, L. (1993). Value orientations, gender, and environmental concern. Environment and Behavior, 25(5), 322-348. https://doi.org/10.1177\%2F0013916593255002

Wilke, H.A. (1991). Greed, efficiency and fairness in resource management situations. European Review of Social Psychology, 2(1), 165-187. https://doi.org/10.1080/14792779143000051

Zsóka, Á., Szerényi, Z.M., Széchy, A., \& Kocsis, T. (2013). Greening due to environmental education? Environmental knowledge, attitudes, consumer behavior and everyday pro-environmental activities of Hungarian high school and university students. Journal of Cleaner Production, 48, 126-138. https://doi.org/10.1016/j.jclepro.2012.11.030 


\section{Authors}

The contribution of co-authors is not equal and can be expressed as follows: B. Borusiak (32\%) prepared the research model (including hypotheses development), research tool and literature review concerning secondhand shopping (in general and in Poland), A. Szymkowiak (27\%) prepared the statistical calculations, D.B. LopezLluch (23\%) prepared the literature review on the environmental concern and its influence on consumer behaviour and second-hand shopping in Spain, P. Sanchez-Bravo (18\%) prepared the discussion and conclusions.

\section{Barbara Borusiak}

Associate professor at Poznań University of Economics and Business, Department of Commerce and Marketing (Poland). Her research interests include sustainability, sustainable consumption, circular economy and retail management.

Correspondence to: Prof. Barbara Borusiak, Ph.D., Uniwersytet Ekonomiczny w Poznaniu, Katedra Handlu i Marketingu, al. Niepodległości 10, 61-875 Poznań, Poland, e-mail: barbara.borusiak@ue.poznan.pl ORCID (i) http://orcid.org/0000-0003-0672-1135

\section{Andrzej Szymkowiak}

Associate professor at Poznań University of Economics and Business, Department of Commerce and Marketing (Poland). His research interests include consumer behaviour, e-business and e-commerce, social media.

Correspondence to: Prof. Andrzej Szymkowiak, Ph.D., Uniwersytet Ekonomiczny w Poznaniu, Katedra Handlu i Marketingu, al. Niepodległości 10, 61-875 Poznań, Poland, e-mail: andrzej.szymkowiak@ue.poznan.pl ORCID (1) http://orcid.org/0000-0001-5673-7093

\section{David Bernardo Lopez-Lluch}

Lecturer at Universidad Miguel Hernández de Elche, Department of Agrienvironmental Economics (Spain). His research interests include wine and food economics and consumer behaviour.

Correspondence to: Dr. David B. López-Lluch, Centro de Investigación e Innovación Agroalimentaria y Agroambiental (CIAGRO-UMH), Carretera de Beniel SN, Km. 3,2, 03312 Orihuela, Alicante, Spain, email: david.lopez@umh.esdavid.lopez@umh.es ORCID (i) http://orcid.org/0000-0001-7901-7208

\section{Paola Sanchez-Bravo}

Ph.D. student at Universidad Miguel Hernández de Elche, Department of Agro-Food Technology (Spain). Her research interests include consumers studies, sustainability and food categories.

Correspondence to: paola.sanchezb@umh.es ORCID (1) http://orcid.org/0000-0002-9855-1999

\section{Acknowledgements and Financial Disclosure}

The authors would like to express their gratitude to anonymous reviewers for their valuable comments of the first version of this paper.

\section{Conflict of Interest}

The authors declare that the research was conducted in the absence of any commercial or financial relationships that could be construed as a potential conflict of interest.

\section{Copyright and License}

This article is published under the terms of the Creative Commons

Attribution - NoDerivs (CC BY-ND 4.0) License

http://creativecommons.org/licenses/by-nd/4.0/ 
